\title{
体育学における哲学的研究の課題と二十一世紀への展望1)
}

\author{
佐 藤 臣彦
}

\section{Subjects of philosophic inquiry in sciences of physical education toward the 21 century}

Tomihiko Sato

\section{はじめに : 問題の所在}

日本体育学会が発足してちょうど五十年，まさ に半世紀が経過し，次の半世紀に向ってのいわば 折返し点に立っている. しかし, 状況論的には, この半世紀のあいだ続いてきた学校体育制度全体 が再編期に突入しており,これまで制度に守られ てきた学校体育の先行きが不透明なものになりつ つある.すでに，大学体育がそうした荒波の真っ 只中におかれていることはわれわれが身をむって 経験しているところであろう。「体育」はいま， 改めてその存在意義が問われているのである.と きはあたかも第二ミレミアムが終わろうとしてい る大世紀末であるが，二十一世紀の体育が，さら により豊かに展開していくためには, 何といって む体育学による学問的支えが必要になってこよ う.その意味で, 体育学の責任は非常に重大であ ると言わねばならないのである.

新しい二十一世紀に向けて，体育学がそうした 役割を果たしていくには，何よりもまず学問力」 を高めていかねばならない：ここで「学問力」と いうのは, 当該の学問が対象とする事実を合理的 に説明するとともに，適切な対処能力を現実に対 して発揮することで世間一般を納得せしめる力量 のことである2). 例えば, 現代医学は, 現在, 大 きな「学問力」をもっていると言えるが，それは， 多種多様な病的現象を理論的に解明するととも
に，治療という形で適切に対処する術を確立する ことで，非常に幅広い社会的認知を獲得し得てい ることに基づいている.「学問力」とは, 結局の ところ,こうした実績の積み重ねによって獲得さ れた社会的信用もしくは信頼にその源があると言 えるのである.

問題は, われわれの「体育学」がこうした「学 問力」を備えているかどうかである，どう，聂屓 目にみたところで，「未だしの感」があるのは否 めない事実であろう.わが国の体育学は，これま で制度によって保証された学校体育というべース があって発展することができた，という側面をも っている. 日本体育学会に所属する会員は，その ほとんどが何らかの教育機関に所属していたり， かつて所属していた人々であって，それでれ体育 教師としての実践経験を持っている. 日本体育学 会という学会組織は，このような学校教育制度に おける体育実践者によって構成され，支えられ て，今日まできたと言える。しかし，逆に考えて 見ると，もし，こうした制度がなかったとした ら, 体育学も成立し得なかったかもしれないので ある.このことは，ことによると，わが体育学は 学問としての autonomy すなわち自律性というも のを確立し得ていないのではないか，という疑問 を浮かびあがらせることになってくる。

他の学問領域では, ある研究部門について独自 の研究施設を立ち上げたり，企業などにおいてそ
筑波大学体育科学系

干305-8574 荻城県つくば市天王台 1-1-1
University of Tsukuba, Institute of sport and health sciences, 1-1-1 Tennodai, Tsukuba-city, Ibaraki 305-8574 
のための研究部門を新設し，それぞれ専門的な研 究者を集めて研究成果をあげるべく猛烈に競いあ う，ということが一般的におこなわれている。つ まり, 研究すべきテーマが課題として立ち上がる と，それに必要な研究施設がつくられ，新たにさ まざまな装置が開発され, そして, 多くの研究者 が問題解明を目指して知力の限りを尽すといった 自律的システムが動き始めるのである. 先端的な 研究部門では，このように解明すべきテーマがま ず初めにあって，それに伴ない必要な施設や装置 や人材が集約され，場合によると非常に大きなシ ステムが構築されることになるのであるが，こう した自律的システムの確立もまた, 「学問力」の 如何を反映するものと言えるたろう。

しかし，わが体育学は，今のところ，このよう な自律的システムをもつには至っていない，体育 学に従事するわれわれは，研究を主体とする機関 に所属する専門的な研究者というよりは，教育機 関に所属するかたわら，それぞれの興味・関心に 基づいて研究に取り組んでいるのが実状なのであ る.われわれは，いわば二足の草鞋を履きつつ体 育学の研究に搭わっているわけであるが，このこ とは，先端的な研究領域におけるような自律的シ ステムから見ると，随分，原始的で牧歌的である ように思われるだろう．しかし，見方を変えれ ば，体育学にあっては，研究に携わるわれわれ一 人ひとりに，研究課題を自分自身で設定する自由 が与えられている，とも言えるのである．研究者 の主体性の確保ということからすると，このこと は，大きな利点であると言えるかもしれない。

ただ，学問力という点からみると，いかにわれ われ自らが主体的に選択し設定した課題ではあっ ても，事実を合理的に説明することができず，現 実に対する適切な対処能力も発揮できないのであ れば，社会的信頼の得られようはずもないことは 明白だろう。したがって，体育学全体の学問力の 蓄積にも繁がってはこないことになるわけで，一 人ひとりに自由が与えられているということは， 逆に言えば, 体育学の学問力が培われるかどうか の責任も，われわれ一人ひとりに掛かってくると いうことになる.もし，体育学が学問力を発揮で
きないとなると，二十一世紀に向おうとする「体 育」そのものの将来にも暗い影を落とすことにな りかねない。われわれが主体的に搭わっている体 育学の責任はまさに重大なのである.

日本体育学会を構成する専門分科会のひとつで あるわれわれの体育原理専門分科会にあっても， 事情は，全く同様であると言ってよいたろう．将 来の体育の展開に対し，われわれの専門分科会む また，学問力をもって貢献していく責務を負って いると言えるのである. 当分科会は，体育学にお ける哲学的な研究課題を担ってきているのである が，このことは，これまで蓄積されてきた研究業 績からも明かであろう. しかし，これから二十一 世紀という新たな世紀に向けての展望を拓こうと するとき, いま一度, 体育学における哲学的研究 部門が担うべき役割について反省しておく必要が あるのではないか. 哲学的研究は, 体育学の学問 力にいかに奇与し，ひいては体育そのものの存在 意義にどのようにかかわりうるのたろうか.

この問題は，きわめて重大かつ広範にわたるも のであるが，今回のキーノート・レクチュアで は, (1)専門的な研究分野の表看板ともいえる, 「体育原理」なのか「体育哲学」なのかという名 称問題, (2)体育的事象を対象とする哲学的研究が 有意性を持つための方略，(3)体育学全体における 哲学研究の果たすべき役割, (4)学校教育から地域 社会にわたる体育的諸問題に対する体育哲学の関 わりの可能性, (5)専門的研究者育成システムの再 検討，という五点について考えてみたい.

\section{1. 名称問題 : 体育原理か体育哲学か？}

まずは，最初の名称問題である．われわれの専 門分科会は，体育学における哲学的な研究課題を 担う分野であるが，現在，名称は，「体育原理」 ということになっている．学問力によって社会的 認知を得ようとするとき，その領域の名称問題 は，ふつう考えられているよりも，はるかに重要 な意味を持つ. というのも, ある研究領域のイメ 一ジは，まずはその名称から喚起されることにな るからである．筆者自身の経験で言えば，大学で の講義で「体育原理」という科目名をはじめて見 
たとき，いったい何をやる授業なのか，皆目見当 がつかなかった．その後，大学で教鞭をとりなが ら, 体育専攻の学生たちでさえ, かなり戸惑って いるのを見てきているので，この印象は，それな りの一般性があると言えよう。

専攻学生でさえそうなのだから，ましてや一般 社会人にとっては，「体育原理」などという名称 は，聞いたことも見たこともないというのが実状 なのではないだろうか．たとえ耳にしたとして も, 内容について具体的イメージを思い浮かべる ことは，おそらく不可能なことたろう．となる と，学問力どころではない，そもそも「体育原理」 という名称自体が，一般のひとびとにとっては存 在しないも同然なのだから，社会的認知の生まれ ようはずもない，ということになってしまうので ある.

では，これまでの体育原理専門分科会における 研究業績の内容を反映する「体育哲学」という名 称はどうだろうか.「哲学」という名称について は，内容的な理解はともかくとして，一般のひと びとにとって，少なくとも「原理」よりは㜕かに 馴染みのものであると言えよう。筆者は, 現在, 筑波大学において，「体育哲学」という科目名で, 学部にあたる体育専門学群や大学院で講義をおこ なっているが3)，新たに入学してきた学生が，よ く，「体育に哲学があるとは思わんかった」など と言っているのを耳にする. 受講生に書いてむら う授業についての感想などを読んでみると，「哲 学は難しいもの」という先入見を強くもっている ことがわかるけれども，講義が進むにつれて， 「哲学って，案外，おもしろいものですね」と言 ってくれる学生む，少数ではあるが出てきてい る4). 全般的に言えば，「哲学」という名称自体 については，彼らはそんなに違和感をむっていな いようである。

たた，一般には，「体育哲学」という名称につ いて，まだをた馿染みのないものと言えるだろ う。ふつう，「体育」と言えば，やはり「身体」 や「からた」といったことが連想されるし，「哲 学」と言えば,「頭脳」や「知性」と言ったこと が連想されるので，この二つを結びつけることに
は，ある種の抵抗感を覚える傾向がある．筆者自 身，専攻を訊ねられて「体育哲学です」と答える と，「体育哲学なんて成立するのですか？」と問 い返されることがしばしばで，これまでそういっ た経験を何度かしてきている．残念ながら，いま のところ, 体育哲学の認知度はきわめて低いと言 わさるを得ないが，しかし，「哲学」という名称 の認知度は「原理」よりも遥かに高いのであるか ら，しかるべき学問的業績によって裏打ちがなさ れれば，「体育哲学」の社会的認知度は急速に高 まっていくたろうと期待されるのである.

従って，われわれの専門領域の学問力にとって は，まず，この名称問題の解決が新たな第一歩を 踏み出す重要なきっかけになるだうう．実を言え ば，この問題については，1981年の第32回大会 における原理専門分科会のシンポシウム,「体育 ·体育学に関する基本的概念の確認と創造につい て」において，筆者自身，「体育原理のこれから の課題」というテーマで報告しており5)，理論上 の問題についてはすでに決着済みである。すなわ ち，日本の体育原理がモデルとしてきたアメリカ の Principles of Physical Education (以下 PPE) は，わが国におけるような哲学的な学問領域とは 考えられておらず，体育に関わる人文系から自然 系に至るさまさま学問領域が積み上げてきた成果 を，体育実践での利用活用という見地から再稨す る，いわば技術的領域とされているのである（図 1 参照).

アメリカのPPEをひもといてみると，体育に かかわるさまざな研究分野，すなわち，哲学は もちろん, 歴史学, 社会学, 人類学, 心理学, 経 営学, 教科教授学, 健康保健学, 生理学, 生化

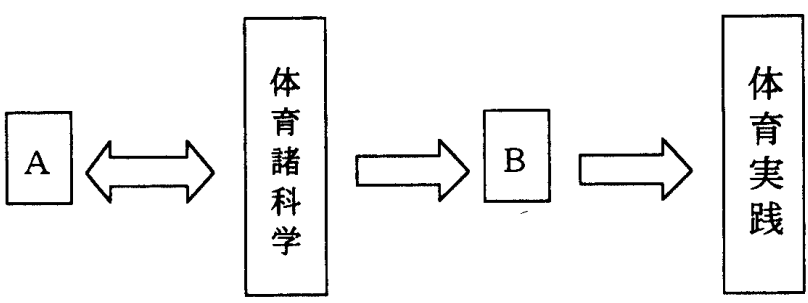

図 $1 \mathrm{~A}$ 領域：わが国の「体育原理」; B 領域：米 国の PPE 
学, 解剖学, 運動力学などなどにおける研究成果 が網羅されていて，とてもとても哲学という単一 の研究領域に収まるものではない。こうしたアメ リカのPPEは，日本の体育原理にはない，大き な特徵をむっている. それは，学問研究の成果を 体育実践の場に取り結ぶという役割りである.

われわれ自身のことを反省してみればすぐに思 い当たるように, 日頃, 体育実践という場で教師 としての教育活動をしていると，広範囲に及ぶ研 究論文に目を通すなどということは，なかなかで きることではない，さまざまな研究領域で，それ こそ，日々，弛むことなく研究成果が生み出され ているのだけれども，それらのほとんどについ て，われわれは何も知らないますに過ごしてい る，あるいは過ごささるを得ないのが実状と言え よう. その結果，実践者としては，いさというと きに役立つような研究がちっともなされていない と嘆くことになり, 研究者としては，これたけ成 果を出しているのに, 現場の実践者はなんら活用 してくれないなどと不満を漏らすことになってし まう.つまり，研究者と実践者とが互いに不信感 をむちつつ乘離しているのである.

こんなとき, 数年に一度の割合で改訂を重ねて いるアメリカのPPE は, 両者を結ぶ架け橋の役 割を担ってくれるのである. 最む新しいPPEを 一冊手に入れて通読してみれば，そこでは，さま ざな研究領域において生み出された最新の知識 知見が，体育実践に役立つような形に編集されて いるのである.つまり，PPEによって，われわ れは，労せずして体育にかかわる学問的な研究成 果の現在を総覧することができ, 人文・社会科学 から自然科学にいたる最新の知識知見を実践に活 用できることになるのである.

このように, アメリカ流の PPE は, 体育諸科 学が生み出す広範囲にわたる成果を体育実践者が 利用活用し易いように加工して提供することで, 両者の間隙を埋める役割を果たしているが（図 1 の B 領域), 残念ながら，このような PPEは, わが国には存在していない。これまで，「体育原 理」が哲学的な学問分野とみなされてきたことに よって（図1のA 領域), アメリカ的な PPE と
しての「体育原理」という発想自体が成り立ち得 なかったのである.

このようなアメリカ的な「体育原理」が成立し てこなかったということは，日本の体育にとって も体育学にとっても，随分，不幸なことだったと 言わねばならない。こうした状況を打破するに は，まずわれわれの「体育原理」が「体育哲学」 へと脱皮し, 名㬰ともにそうした役割を担ってい くことを明確化する必要がある，つまり，われわ れの専門分科会の名称を「体育原理」から「体育 哲学」へと変更し，そのうえで,ささらにメリカ 的な体育諸科学と体育実践とを取り結ぶ新たな 「体育原理」を，日本の状況に応じた形で具体化 するように initiative をとっていくべきなのであ る. 学問的成果を実践の場で検証し鍛えていくこ とは, 学問力養成の基本であって, 新しい「体育 原理」の確立は，そうした検証に大いに役立つこ とだろう.もちろん，こうした「体育原理」を作 り上げていくには, 体育哲学たけでは不可能であ る.筆者は, 新しい世紀に向けての新たな「体育 原理」の構築を, 体育学会の総力を結集して取り 組むべき課題であると考えているが，この課題 は, 体育学全体が自らの学問力を高めていくため にも，この上ない試金石になるはずである.

\section{2. 体育と体育哲学}

次に，第二番目の問題に移万う。すなわち，体 育的事象を対象とする哲学的研究が有意性を持つ ための方略についてである.これ以後,「体育学 における哲学的研究分野」などというまどろっこ しい言い方はやめて, 単に「体育哲学」というこ とで話を進めていくことにしたい。

再三, 述べてきたように, 学問力の基盤は, 対 象とする事実の合理的な説明能力と現実への適切 な対処能力を示すことで, 広く社会的認知を獲得 するところから生なれてくる，残念なことに， 「体育哲学」は，これまで名称さえままならなか ったのであるから, 現状では学問力も何もあった ものではない，しかも，先に見たように，「体育」 と「哲学」とは何か柾遠なもののようにもみなさ れてきているのであるから，条件としてはきわめ 
て劣悪な状況にあると言わねばならない，要する に,「体育哲学」は，学問としての認知が大きく 立ち後れているのであって，このことは率直に認 めなければならないだろう。

ただ「哲学」ということであれば，名称の上 での認知度は高いわけたから，体育哲学が学問力 を備えうるかどうかは，一にも二にも学問的業績 の蓄積如何にかかっていると言えるだろう。「体 育哲学」とは，ご簡単に言えば，体育という事 象を哲学的に研究していく領域たということにな る. 筆者は，筑波大学に入学してくる体育専攻の 新入生に対し，まず，「君たちがこれから専門に 学ほうとしている体育とは, いったい, 何なのた ろう？」と問いかけ，少しく考えさせるのを常と している.しばらくするうちに，彼らは，ほほ例 外なく，ある種の「戸惑い」の表情を浮かべるこ とになるが，それは，こうした問いに対し，彼ら 自身，なんら答える術をもっていないということ に気づくからなのである.「体育とは何かなんて, これまで考えたこともなかった」という学生が随 分いるのであるが，この問いは，彼らにとって， 最初の知的な通過儀礼になっているようである.

こうした現状は，大きな問題を孕んでいる。 と 言うのも, 筑波大学の体育専門学群に入学してく る学生でさえもが，「体育」の何たるかについて の明確な理解をむっていないということは，世間 一般にあっては，なおさらその傾向が強いだうう と予想されるからである.「体育学」はおろか, そもそも，打抢もとの「体育」ということについ てさえ，ほとんど一般的認知は得られていないと 考えた方が，むしろ現実的なのかむしれないので ある.むし，「体育」についてのきちんとした理 解がないのであれば，新しい世紀に向けた「体育」 の発展的展開なんそ，「絵に描いた餅」というこ とになってしまうだうっ.そして，このことは， 直ちに体育学全般の学問力の如何に跳ね返ってく る.下手をすれば，体育学そのものが砂上の楼閣 と化してしまう恐れさえあるのである．このよう に考えてくると, 体育学の将来も,「体育」の何 たるかについての明確な理解にかかってくると言 えるのである.
「体育とは何か？」という問いは，まさに哲学 的問いの最たるものと言えよう. おそらく，体育 哲学以外に，この問いに対して十全に答えうる専 門領域は存在しないはずである，その意味からす れば，これまで大きく立ち後れてきた体育哲学 は，いきなり体育および体育学の将来がかかる， 先端的かつ重大な課題を背負うことになるのであ る.このことに関して，ひとつたけ指摘しておく ことにするが，従来の体育論では，体育概念に対 し，もっぱら，身体論を中心とするアプローチが なされてきた．しかし，周知のように，体育が身 体教育を原義とするのである以上，体育概念を明 らかにするには，限定詞の身体の方ではなく，基 底詞である教育の方にまず焦点を合わせなければ ならないはずである、こうした方略のもと, 筆者 は,「体育哲学叙説」という副題をもつ『身体教 育を哲学する』6) と題された著書を公刊している ので，参照いただければ幸いである.

ともあれ，体育概念をめぐっては，現在も多く の混乱がある. その代表的なものが，「体育」と 「スポーツ」をめぐる概念問題であろう。いった い, 体育とスポーツとは, 同じものなのか, 違う ものなのか. 違うとすればどのように違うのか. この問題について, 現在, サッカー協会会長の岡 野俊一郎氏は，かつて筑波大学で日本体育学会第 37回大会が開催された折り（1986年）「体育と スポーツとの区別について，これまで納得できる 明快な説明を聞いたことがないので，是非，体育 の研究者にはこの問題の研究に取り組んでいただ きたい」といった趣旨の発言をなさっていたと思 う7). 体育とスポーツに関する概念的区別の問題 については, 筆者も, 当専門分科会の機関誌であ る『体育原理研究』の第22号に，「体育とスポー ツの概念的区分に関するカテゴリー論的考察」と 題する論文 ${ }^{8)}$ を寄せているので，これをた参照い たたければ幸いである。

概念問題については，身体教育を原義とする普 通名詞としての「体育」と，学校教育における教 科名としての「体育」との混用も, 重要な問題で ある.しかも，この混用の実態は，ほとんど自覚 さえなされていないのでことは深刻である ${ }^{9)}$. 体 
育哲学は，このような，通常，見過ごされがちな 問題を問題として自覚化し，しかるべき解決の道 を探って，混乱した現状をきちんと論理化して説 明するという役割を担っている. そうした基本的 な課題を引き受けて理論的な解決を提示していく ならば, 体育哲学の学問力は大いに高まることに なるに違いない。

体育事象を表層においてのみならず，構造的・ 本質的な次元において理解しようとすれば，要す るに「体育哲学」をもってする外はないのであっ て，こうした課題に答えることができれば，当然 のことながら, 体育そのものの存在意義も明確に なってくるであろう. その意味で, 体育哲学は, 体育というものの理論的解析を押し進める上での 基本的役割を担っており, 研究領域としての充実 が望まれるのである.

\section{3. 体育学における体育哲学の役割り}

次の第三番目の問題に移ることにしたい，すな わち，体育学において体育哲学が果たすべき役割 りについてであるが，この問題は，どう，考えた らよいのだろうか，体育哲学は，体育学全体に対 して，どのような貢献ができるのであろうか.

まず第一に考えられることは，体育学そのもの の学的な専門性を基礎つけるという役割りが考え られよう.「はじめに」において述へたように， 戦後における体育学の成立は, 解決されるべき理 論上の問題群がまず存在し，必要に迫られて構築 されてきたというよりも，教育機関に所属してい る体育教師が，とにかく自分たちの研究発表の場 を確保しようということから出立したと言ってよ い、そうした先達の先見性と努力があって，われ われは，いまこうして学会活動をすることができ るのであるが，ただわれわれの「体育哲学」に してむ, 他の専門分科会, 例えば, 「体育史」「体 育社会学」「体育心理学」などなどにしても，そ れぞれ, 哲学プロパー, 歴史学プロパー, 社会学 プロパー，心理学プロパーといった，いわゆる 「親学問」が一方に控えている.

そうなると, 体育哲学は, 哲学に関する専門学 会の一ブランチとして位置づければいいではない
かという議論む, 当然のことながら出てこよう. このことは，なにも体育哲学に限ったことではな い，体育学におけるそれぞれの個別分野は，大な り小なり「親学問」を頂いているのであるから, この問題は体育学全体に及ぶ問題であると言えよ う。つまり，それぞれの親学問があるのに，その 下請け的な立場にある体育諸学に，はたして学問 としての独自性が存在するのか，という問題が生 じてきてしまうのである. むし，この問題が解决 されなければ, 体育学の体育学たる所以が存在し ないということになり，それこそ，学問としての 危機存亡にかかわることになってしまう．この問 題を引き受けることができるのむ, やはり体育哲 学以外にはないであろう. 現在, 名称さえ認めら れていない体育哲学ではあるが，担うべき課題は 体育学全体にとってもきわめて重大なものなので ある。

そもそも学問の学問たる所以はどこにあるのだ ろうか. 日本語での学問という言葉は, 近代西欧 語の science（英・仏）, Wissenschaft（独）など が含意する意味内容を踏まえた用語として，今 日，機能しているが，こうした西欧語を基準にお くなら, 学問と科学とは全く同義であると言うこ とになるだろう。これらの西欧語は，語源的には scientia（羅）あるいは wissen に由来し，いずれ も「知」を意味しているが10), 要するに, 学問 あるいは科学とは，なによりもまず「知る」とい うことに根拠が求められるのである.

問題は，何をどのように「知る」ことが学問と しての条件を満たすことになるのかということで ある．試みに代表的な国語辞典をひもといてみる と,「世界と現象の一部を対象領域とする経験的 に論証できる系統的な合理的認識」(『広辞苑』第 四版，「科学」の項）といった定義が与えられて いる. すなわち, 学問 (あるいは科学) という知 の形態が成立するには，まず，(1)或る特定の事柄 が研究対象として措定されていること，さらにそ の事柄について，(2)経験的に論証できるような系 統的で合理的な認識の提示, の二つが要件とされ ているのである。これらの二要件のうち, 前者 は，それぞれの個別学問分野がおのおのの研究対 
象を特定するところに生まれてくる「専門性」に かかわる規定であり, 後者は, 学問一般の知的形 態にかかわる規定であると言えよう.

「ある特定の事柄が研究対象として措定される」 ということに個別学問分野の専門性の如何がかか っているのだとしたら，体育学の専門性は，まさ に「体育」ということに根拠が求められることに なってこよう。つまり，体育学の専門性の所以 は，「体育」という事象が他の事象と代替不能の 独自性を有しているという点に求められることに なるのである．とすると，前節でむ述へたような 体育哲学による体育概念の本質究明は，体育学そ のものの対象性（objectivity）を明証化すること に棌がり，体育学の専門性確立に向けての大きな 戦略的意義を有していると言えるのである。な お,この問題の詳細については, 『体育学研究』 に「体育学の対象と基礎づ」というタイトルで 論文を寄せているので参照していただきたい11)。

本節の問題に関し，もう一つ, 取り上げておき たいことがある。それは，体育哲学が担うべき 「学問批判」ということである。これまで, 体育 学の学的基礎づけということで体育哲学の役割り を見てきたが，一方で，学問批判という役割りに ついても見ておかねばならない，むちろん，「批 判」といっても，「非難」ということでは毛頭な い.「非難」というのは，「気に入らない」とか「良 くない」とか「けしからん」とか, 要するに感情 的な次元での反発や反応であるが，「批判 critique」は，もともとがギリシア語の「見分ける kritikos」ということからきており，対象をきち んと分析するといった知的なレベルでの操作を意 味している. 従って,「学問批判」とは, あくま でも体育諸科学の現状を分析し，もし，問題があ るようなら，それをきちんと理論的に明確化する という営みである.

かつて, 哲学が学問の現状を批判的に分析し, その結果に基づき学問の進むべき方向を指し示す ことで，新たな進展のきっかけになったことがあ った。 むし，体育哲学が，体育諸科学に対してこ うした役割りを果たすことができるなら，体育学 に大きく貢献することになるのは明かであろう.
研究課題そのものが袋小路に入ってしまって展望 が開けなくなるといったことは，比較的よく見受 けられることであるが，そのような現状を分析し て然るべき問題を摘出できれば，それ自体が有益 な示唆となりうるはずである。しかし，実際に は，こうした批判・分析はきわめて困難な作業で あって，何よりもまず，体育哲学に携わるわれわ れ自身がしっかりと勉強しなければならないたろ う. そして，意義ある成果の蓄積がなされていけ ば，やがては，こういった課題に対しても対処し 得るだけの力量を持つことができるようになるは ずである，そうなったとき，体育哲学は，明らか に学問力を発揮していることになる．そのときの 来たらんことを目指して，われわれは努力を重ね ていかねばならないのである。

\section{4. 体育的諸問題と体育媔学}

第四番目の問題に移ることにしたい，学校教育 から地域社会にわたる体育的諸問題に対する体育 哲学の関わりの可能性についての問題である.

ギリシア以来の哲学が担ってきた役割りは，大 きく言って二つある.一つは，「対象の原理論的 構成」である，例えば，存在とは何か，時間とは 何か，認識とは何か，人間とは何か，などなどと いった基本的問題群が哲学的課題の代表例になる が，なんであれ対象として措定した事柄につい て，これ以上はさかのほれないような根本的なと ころから出発しつつ, その全体像を理論化するこ とによって把握する営みが，ここで言う「対象の 原理論的構成」である．体育哲学の場合，体育と いう対象について, 誰もが認め得るような前提か ら出発し, 論理的な一貫性を保ちつつ, 体育概念 を理論的に構成するという仕事がこれにあたる が，この課題は，すでに，第二節や第三節におい て述べてきたことに重なるものである.

もう一つは，上の第三節の後半に述へてきたこ とであるが，「現状批判」あるいは「現状分析」 ということである. プラトンが描くソクラテスを 思い浮かべてもらうとわかり易いと思うが，彼が 実践していたことは，ひとびとが知っていると思 いなしている事柄を，分析的な問答法によって吟 
味し，批判することであった。プラトンは，こう したソクラテスの営みに哲学者というものの原型 を見いたしたのであるが，このような分析的・批 判的な営みは，言ってみれば，哲学々いうものの 成立とともにあるもので，以来，哲学史全体を貫 く知的べクトルとして今日に至っている.

分析あるいは批判のベクトルは，第三節で見た ように，学問の現状に対しても向けられるが，さ らに広く，つねに流動的で変転きわまりない現実 そのものに対しても向けられる．われわれがこう した現実に対峙し，それらを分析・批判をしてい くには，当然のことながら，何らかのしっかりし た足場・根拠が必要となってくる．こうした批判 精神を支える根拠が，まさに上に述べた原理論に 他ならないのである. 体育哲学が対峙することに なる現実は，さしあたり，体育的現実ということ になるが，体育的現実といってもきわめて広汎に わたるのであるから，そもそもどんな現実を分析 対象とすればよいのか，そのことを特定するだけ でもすでに大きな問題である．体育的現実という のは，言わばのっぺらほううの状況であって，問題 を見いだす眼力がなければ何もないように見えて しまうのである。

因久に，現在，学校体育や地域社会における体 育の現実には，どんな問題があるのだろうか．筆 者が問題と見るところの事例をいくつか取り上げ てみよう，第一は，教育概念としての体育という 認識の立ち後れ，第二は，教科体育といわゆる部 活動における実践形態の混乱，第三は, 部活動に おける専門性の容認とその位置づけ，といった問 題である.

第一の問題は，体育的現実の全体にかかわる問 題であるが，もちろん，体育概念についての原理 論を前提にしないと，分析・批判は成り立たな い，確かに「体育」ということばは，現在，広く 普及しているけれども，しかし，ほとんどの場 合，スボーツなどのような身体活動と同様な意味 内容において把握されているのが現状である．体 育という用語が身体教育を原義とする教育概念と して出立しているいう事実を，知識としては承知 している体育学研究者でさえも，しばしば，体育 を身体運動を意味する用語として用いている例
が，それこそ枚挙に层がないほど目にすることが できる．況わんや一般においてをや，ということ になるが，人間という存在にとってなくてはなら ない教育概念としての体育を明確化し，近い将来 に向けて，そうした概念を通念化し一般化してい くという方略は，体育哲学による地道な現状分析 あるいは現状批判によってのみ達成することので きる課題であろう.

第二は，教科体育といわゆる部活動における実 践形態の混乱をめぐる問題である。これも，随 分, 根の深い問題であるが，体育実践の第一線に 立つ体育教師は，ほほ例外なく，若いころから長 期にわたって特定のスポーツ種目にかかわってき ており，それぞれがスポーツに関する深い知識と 経験を持ち併せている。こうした経験は，ほとん どの場合，いわゆる「部活動」を通して培われて きたものであると言ってよいだろう。この部活動 は，あるいは日本独特の制度だと言っていいかも しれないが，体育教師として生徒の前に立つまで は，実技指導といっても，部活動を通して得られ た経験がおそらくほとんどすべてであろう．そし て，教科体育を担当することになった体育教師の 大部分は，子どもたちを前にしたとき，部活動を 通して得た経験をもとに実技指導に当たることに なってしまうのである。

現行では, 教科体育において, 一つの種目に費 すことのできる時間枠は，一学年につき，せいぜ い十時間といったところだろう。このわずかな時 間の中で，自分が専門に学んできた方法論によっ て子どもたちを指導しようとすれば，結果が不首 尾に終わるであろうことはあまりに明白である. 一方で，体育教師は部活動の顧問としても活動す ることになるが，こちらでの指導時間は，事実 上，無制限であると言える，当然のことながら， 指導の効果は目に見えて上がってくる，成果のさ っぱり上がらない教科体育と指導効果絶大な部活 動との狭間に立ったとき，体育教師の気持ちは， どうしたって部活動に傾いてしまうことになるだ ろう。教科体育での気持ちの乗らない指導は，子 どもたちにも敏感に感じ取られ，やがて，体育に ついてのマイナスイメージが形成されていくこと に慗がってしまいがちである。 
この問題は, 体育教師自身に, 教科体育と部活 動とでは, ねらいも指導方法論む全く異なるのだ という自覚がなければ解決され得ない。教科体育 では，特定の運動種目を専門的に教えるというよ り，あくまでも教材として，すなわち，その種目 をどのようにアレンジし活用すれば子どむたちの 発育発達に役立てうるのか，そういった観点から 取り扱われなければならないのである。むちろ ん，それぞれの運動種目は多様な側面をもってい るので，それらをどう活用するかは，まさに体育 教師の力量にかかってくる. 教材研究の意味む， 本来は，こうした点にこそあるはずである。こう した教材研究が，実際の指導のなかで検証され， さらに修正が加えられながら蓄積されていくな ら，教科体育は大きな財産をもつことになり，評 価も大いにあがることになるだろう。そのために は，まず，教科体育と部活動との違いを明確化す る必要がある．体育哲学は，この問題についての 理論的根拠を提供することができるのである.

第三の問題は，部活動における専門性の容認と その位置つけけにいてであるが，現在，学校体育 において，部活動は大いに摇れ動いている．指導 要領でも部活動の位置つけけ暧昧なままで, 最近 では，学校という枠からいわゆる社会体育に移管 しようという動きが垣間見えている。これまで, 部活動は，学校体育においてきわめて大きな役割 をはたしてきた，というのも，多くの子どもたち に，特定の事柄に自分自身のすべてをかけて取り 組むといった貴重な体験の場を提供してきたから である.こうした体験は，子どもたちにとってか けがえのないもので, 部活動は, 望むものには誰 に対してもこうした場を提供してきた。この事実 は、どんなに評価しても評価しすぎることはない だろう。

二十一世紀に向けての体育を考えるのであれ ば，部活動を学校体育から閉め出すなどという愚 かなことをするのではなく，むしろ，教科体育と 並ぶ学校体育の両輪として積極的に位置つけるべ きであろう.たた，そのためには整備すべきこと が沢山ある.教科体育と部活動との役割りをきち んと区別するということはもちろんであるが，部 活動についていえば，その専門性をもっときちん
と評価して対処する必要があろう. 現在, 部活動 の顧問といっても，専門的な指導力を持つ教師は むしろ少数で，ほとんどの場合，何ら専門知識を 持たないままに指導に当たっているのが現状であ る、全体を見渡せば，それぞれの運動種目につい ての専門知識を持つ多くの体育教師がいるのであ るから，そうした力が結集されれば，総体として の専門性は格段に向上するたろう。また，部活動 の指導は，現在，ほとんどボランティア同然のあ りさまであるが, 専門性を高めていくと同時に， そうした活動に対し，きちんとした対価が支払わ れるべきである.こうした方向に進んでいけば， 新しい世紀の体育は，豊かな成果を誇ることがで きるようになるであろう。

以上，とりあえず，体育哲学の現実に対する commitment の事例としていくつかのことを取り 上げてきたが，こうした諸問題に対し，明晰な理 論的分析を加えてしかるべき解決の方向性を示す こともまた，体育哲学が担うべき学問的な責務で あろうと考えられるのである。

\section{5. ニ十一世紀に向けての研究者育成システム}

最後の課題になるが，専門的研究者育成システ ムの再検討という問題について見ておきたい．た だ,この問題は, 需要と供給の関係で決まるとい う側面をもっているので，ここでは，ごく簡単に 触れるにとどめる。

体育の教員養成制度については，現在，一応の 確立をみているが，体育学研究者の養成について は，大きく立ち後れているのが現状である，そも そも，体育学研究者に対する社会的需要があるの かと問われれば，現実は，なかなか厳しいと言わ ねばならないだうう，せいぜい，大学のポストに 需要が見いだせるくらいで，それも先細り状態に あることは周知の通りである．ましてや体育哲学 についてはな执さらのことであって，現状を見る 限り，将来の展望は決して明るいものとは言えな いたろう。しかし，体育が，二十一世紀に向けて 雄々しく羽ばたいていくためには，どうしたっ て，体育諸科学や体育哲学のサポートが必要にな ってくる，体育学や体育哲学が，新たな世紀に向 けて，それなりの学問的・社会的責務を果たして 
いくには, やはり研究者の養成システムの確立が 不可欠となってくるはずである.

学問的専門性を確立するには，まず，専門的訓 練を積んた研究者をいかに育成するかが課題とな ってくる. 体育学の場合, なんと言っても歴史が 浅く, 学問上の専門的訓練という点で決定的に立 ち後れている．また，研究の自ずからなる水準の 確立という点でも同様である，一言でいえば，体 育学にあっては，いまたアカデミズムが未成立な のである. アカデミズムとは，暗黙に了解された 研究水準の維持機構であると言えるが，わが体育 学にあっては, 残念ながら，このようなメカニズ ムはいまだ機能してはいない，体育学では，言っ てみれば何でもありの状況で，生み出される研究 成果もさまざまな水準のものが入り交じり，累積 性に乏しいのが実状であろう。

このような現状を打破していくには，やはり， 一人ひとりの研究者としての力量を高めていく以 外に道はない. 制度論的には, 学位の取得機構を 払大的に充実させていくということがひとつのポ イントになるであろう.このことについては, 少 しつうつではあるが改善の方向に向かっているよう に見受けられる.しかし，現職に対する門戸は， 依然としてまだだ狭いと言わなければならな い、しかし，狭いとはいってむ門戸は開かれつつ あるのたから，あとは，研究者としてのチャレン ジングな意欲次第であるということになってこよ う. 現在の状況に生きるわれわれは，とりあえ ず，自らをかけて挑戦していくほかはないのであ る.こうしたチャレンジ精神が実を結んだとき， 体育学は学としての水準を自ずと上昇させること になるだろう。そのとき，われわれの体育学，そ して体育哲学は, 現実に対する学問力を発揮でき る条件を整えたことになるのである.

\section{おわりに}

以上, 体育学における哲学的研究の課題と二十 一世紀への展望と題して，いくつかのポイントを 取り上げて述べてきたが，われわれの領域が担う べき課題は重要かつ多岐にわたるむのであって, 二十一世紀に向けての体育および体育学の進展に 大きく寄与できるものであることを確認し得たの
ではないかと思う，ただ，それが現実に意義ある ものとなるには，何よりもわれわれ自身による不 断の研鑽が不可欠であろう。こうした努力なし に，「自ずと学問力が発揮される」などというこ とはあり得ないのである．このことを自戒しつ つ, キーノート・レクチュアを終えることとした い.ご静聴に深謝.

\section{注}

1）平成11(1999)年10月 8 日, 於: 東京大学·駒場.

2）佐藤臣彦（1999）体育学の対象と学的基礎. 体育 学研究第44巻第 6 号, 484頁. なお，「学問力」 という用語は，桑原武夫の「文化力」という語法 にヒントを得たものである. 桑原武夫 (1981)「文 化力」ということ. 桑原武夫集第十巻所収, 岩波 書店. 初出: 1979年 9 月6日, 朝日新聞.

3）筑波大学体育専門学群では, 平成 $2(1990)$ 年度よ り,「体育哲学」という名称が卒業研究領域名の ひとつとして正式に採用され，今日に至ってい る.

4）因みに，平成 2 年度以来，平成11年度に至る 10 年間の体育哲学専攻生の累積数は, ちょうど40 名, 年平均 4 名といったところである. 筑波大学 体育系教育・研究組織外部評価実行委員会 (1999 年）筑波大学体育系外部評価報告書. 85頁. な お，当資料では平成 10 年度までの累計となってい るので, 平成11年度については実数 5 名を加えて 計算した。

5）佐藤臣彦（1981）体育原理のこれからの課題. 体 育原理専門分科会夏期合宿研究会レポート, 昭和 56年度, 20-26頁. なお，体育原理そのものの包 括的な批判的検討は，佐藤臣彦 (1980) 体育原理 の批判的検討一スポーツ哲学への予備作業一. 体 育・スポーツ哲学研究第 2 巻, 32-55頁において なされている.

6）佐藤臣彦（1993）身体教育を哲学する一体育哲学 叙説一。北樹出版.

7）日本体育学会第37回大会特別シンポジウム「未来 社会における体育・スポーツに期待するもの」. 1986年11月27日，於：筑波大学.

8）佐藤臣彦（1992）体育とスポーツの概念的区分に 関するカテゴリー論的考察. 体育原理研究第22 号, 1-12頁.

9）詳しくは，佐藤（1993），225-230頁を参照され たい.

10）田中美知太郎（1969）学問論. 筑摩書房, 50頁.

11）佐藤臣彦 (1999)，483-492頁. 